\title{
Changes in production and mammary metabolism of dairy cows in response to essential and nonessential amino acid infusions
}

\author{
L. Doepe ${ }^{* 1,2}$ and H. Lapierre† \\ *Department of Agricultural, Food and Nutritional Science, University of Alberta, Edmonton, Alberta, Canada T6G 2P5 \\ †Dairy and Swine Research and Development Centre, Agriculture and Agri-Food Canada, STN Lennoxville, Sherbrooke, Quebec, \\ Canada J1M 1 Z3
}

\section{ABSTRACT}

This study was undertaken to increase our understanding of the need of the mammary gland for the different types of AA and how the mammary gland alters its metabolism in response to a variable AA supply. Eight lactating Holstein cows $(61 \pm 4$ DIM) were used in a replicated $4 \times 4$ Latin square balanced for residual effects with 14-d periods. The diet was formulated to supply $100 \%$ of the net energy requirement and $72 \%$ of the metabolizable protein requirement. The 4 treatments were 1) abomasal infusions of water, 2) essential $\mathrm{AA}$ at $359 \mathrm{~g} / \mathrm{d}, 3)$ nonessential $\mathrm{AA}$ at $356 \mathrm{~g} / \mathrm{d}$, and 4) essential AA at $359 \mathrm{~g} / \mathrm{d}+$ nonessential $\mathrm{AA}$ at 356 $\mathrm{g} / \mathrm{d}$ (total of $715 \mathrm{~g} / \mathrm{d}$ ). The infusates had the same AA profile as casein with the exception that Met was increased to maintain a 3:1 ratio of digestible Lys to Met and because of solubility limitations all the Tyr was replaced by Phe and part of the Glu was replaced by Gln. Milk yield and milk protein yield were increased by the essential AA treatments compared with the other treatments. Mammary uptake of $\beta$-hydroxybutyrate plus lactate tended to increase with the essential AA treatments, whereas glucose mammary uptake tended to be higher with the nonessential AA treatments. With the essential AA treatments, the mammary uptake:milk protein output ratio for the group 1 AA (His, Met, Phe, Trp, and Tyr) did not differ from 1 but tended to increase; the ratio for the group $2 \mathrm{AA}$ (Ile, Leu, Lys, and Val) did increase, significantly exceeding unity when essential AA were infused. These results indicate that the mammary gland alters differently its uptake of both AA and energy-yielding nutrients in response to the amount and profile of AA presented to it and that even under situations of protein deficiency nonessential

Received December 24, 2009.

Accepted March 24, 2010

${ }^{1}$ Corresponding author: ldoepel@ucalgary.ca

${ }^{2}$ Current address: University of Calgary Faculty of Veterinary Medicine, 3280 Hospital Drive NW, Calgary, Alberta, Canada T2N $4 \mathrm{Z} 6$
AA supplementation does not enhance milk and milk protein synthesis.

Key words: mammary, amino acid, energy, nutrient

\section{INTRODUCTION}

All tissues use AA for protein synthesis but, on a net basis, the mammary gland (MG) of the lactating dairy cow is the largest net user of AA in the body. Although the uptake of essential AA (EAA) by the MG is either sufficient for group 1 AA (His, Met, Phe+Tyr, and Trp) or in excess for group 2 AA (Ile, Leu, Lys, and Val: Clark, 1975; Mepham, 1982) of the amount needed for milk protein output, the uptake of the nonessential AA (NEAA) cannot account for all the NEAA incorporated in milk protein (Clark, 1975; Guinard and Rulquin, 1995; Doepel et al., 2007). This means that the MG must synthesize NEAA to cover the need for milk protein synthesis. The most probable source of $\mathrm{N}$ and $\mathrm{C}$ to make these NEAA would be the EAA taken up in excess relative to milk output by the MG. In earlier studies conducted in vitro, labeled $\mathrm{C}$ from Leu was incorporated into Glu in mammary tissues of the goat (Roets et al., 1979) and the cow (Wohlt et al., 1977). Similarly, the N of Leu and Lys was transferred to a variety of NEAA in the goat (Rubert-Alemán et al., 1999) and the cow (Lapierre et al., 2003). The magnitude of NEAA synthesis from the $\mathrm{N}$ of Lys taken up in excess was altered by Lys supply (Lapierre et al., 2009).

If EAA are being directed toward NEAA synthesis, then provision of the NEAA should alleviate the need for their synthesis from EAA, thus freeing the EAA for milk protein synthesis. This hypothesis, however, was not supported in the study of Metcalf et al. (1996), in which the milk protein response was no greater when both EAA and NEAA were infused compared with when only EAA were infused. Similarly, duodenal infusion of gelatin, in which EAA made up only $25 \%$ of the total AA, did not affect milk protein yield whereas isonitrogenous infusion of $\mathrm{CN}$ ( $56 \% \mathrm{EAA})$ increased it (Rulquin, 1986). Altogether, these studies suggest that NEAA supply does not have a major effect on milk protein yield. 
At the MG level, CN infusion in the duodenum, which induced additional milk protein synthesis, increased the excess mammary uptake of group 2 EAA simultaneously to the deficit of NEAA relative to milk output (Raggio et al., 2006) and, in the absence of any additional energy substrates, increased BHBA uptake but did not affect glucose uptake (Lemosquet et al., 2009b). However, the response of the MG to the different types of AA is not yet known. How the MG alters its metabolism in response to a variable AA supply is crucial for determining AA requirements and for maximizing the efficiency of use of MP. We hypothesized that supplementation of NEAA in addition to EAA would increase mammary uptake of the NEAA and alter the uptake of the group 2 EAA and some energy substrates compared with when only EAA were supplied. Thus, the objectives of the current study were to determine 1) how net mammary uptake of AA and energy substrates changes when the supply and type of AA are altered and 2) how the alterations in $\mathrm{MG}$ uptake are related to changes in milk production and composition.

\section{MATERIALS AND METHODS}

\section{Treatments and Feeding}

Animals were cared for according to the Canadian Council on Animal Care (1993) guidelines, and all experimental procedures were approved by the Animal Care and Use Committee of the University of Alberta (Edmonton, AB, Canada). Four first-lactation and 4 second-lactation Holstein cows were surgically implanted at $33 \pm 5$ DIM with abomasal catheters as described by Doepel et al. (2006). At 61 DIM, cows (BW: $587 \pm$ $45 \mathrm{~kg}$ ) were randomly assigned within parity to one of 4 treatments in a replicated $4 \times 4$ Latin square design, balanced for residual effects, with 14-d periods. The treatments were distributed according to a factorial design as 1) abomasal infusions of water (CTL), 2) a mixture of EAA at $359 \mathrm{~g} / \mathrm{d}$ (ETL), 3) a mixture of NEAA at $356 \mathrm{~g} / \mathrm{d}$ (NETL), and 4) the combination of $359 \mathrm{~g} / \mathrm{d}$ of EAA and $356 \mathrm{~g} / \mathrm{d}$ of NEAA, for a total of $715 \mathrm{~g} / \mathrm{d}$ (TOT). The profile of AA in the infusates was the same as that found in CN (Table 1) with the exceptions that Met was increased to maintain a $3: 1$ ratio of digestible Lys to Met (total dietary + infusion) and because of solubility limitations all the Tyr was replaced by Phe and part of the Glu was replaced by Gln. In addition, the amount of EAA was set at $50 \%$ of TOT so that the recommendations for EAA supply of Doepel et al. (2004) were met. The AA were dissolved in hot tap water every 2 or $3 \mathrm{~d}$ and were infused continuously through a peristaltic pump in a daily volume of $10 \mathrm{~L} /$ cow $(416 \mathrm{~mL} / \mathrm{h})$ for the duration of the study.
Table 1. Daily amount of AA infused abomasally into the cows for each treatment

\begin{tabular}{lccc}
\hline AA, g/d & ETL & NETL & TOT \\
\hline Arginine & 24.1 & & 24.1 \\
Histidine & 19.1 & & 19.1 \\
Isoleucine & 41.8 & & 41.8 \\
Leucine & 69.5 & & 69.5 \\
Lysine & 58.8 & & 58.8 \\
Methionine & 23.0 & & 23.0 \\
Phenylalanine & 34.7 & 35.1 & 69.8 \\
Threonine & 30.5 & & 30.5 \\
Tryptophan & 10.6 & & 10.6 \\
Valine & 46.8 & & 46.8 \\
Alanine & & 20.7 & 20.7 \\
Aspartate & & 21.3 & 21.3 \\
Asparagine & & 26.3 & 26.3 \\
Cysteine & & 4.4 & 4.4 \\
Glutamate & & 41.7 & 41.7 \\
Glutamine & & 93.0 & 93.0 \\
Glycine & & 62.6 & 11.3 \\
Proline & & 39.5 & 62.6 \\
Serine & & 39.5 \\
Total & 358.9 & 714.8 \\
\hline
\end{tabular}

${ }^{1} \mathrm{ETL}=$ essential AA infusion at $359 \mathrm{~g} / \mathrm{d} ; \mathrm{NETL}=$ nonessential AA infusion at $356 \mathrm{~g} / \mathrm{d}$; TOT $=$ essential AA infusion at $359 \mathrm{~g} / \mathrm{d}+$ nonessential AA infusion at $356 \mathrm{~g} / \mathrm{d}$, for a total of $715 \mathrm{~g} / \mathrm{d}$.

${ }^{2}$ Amount of Met in the infusate was increased to maintain a 3:1 ratio of digestible Lys to Met (total dietary + infusion).

${ }^{3}$ Because of low solubility, Tyr was replaced with Phe in the NETL and TOT treatments; a portion of the Glu was also replaced by Gln because of solubility constraints.

Cows were fed a TMR that was formulated to supply $100 \%$ of the cows' $\mathrm{NE}_{\mathrm{L}}$ requirements but only $72 \%$ of the MP requirements based on DMI of $16 \mathrm{~kg} / \mathrm{d}$ and pretrial milk yield of $34.5 \mathrm{~kg} / \mathrm{d}$ (NRC, 2001; Table 2). Cows were fed once daily except for the last $4 \mathrm{~d}$ of each period, during which they were fed 6 times daily to maintain steady state conditions. Throughout the study, cows were fed the average amount of their ad libitum intake measured the $4 \mathrm{~d}$ before the initiation of the project. Orts, when present, were recorded and sampled during the last $4 \mathrm{~d}$ of each period. Moisture content of the forages was determined weekly and used to make ration adjustments to ensure constant delivery of DM. Cows had free access to fresh water and were milked twice daily at 0430 and $1530 \mathrm{~h}$. Milk was sampled at each milking on the last $7 \mathrm{~d}$ of each experimental period.

\section{Blood Sampling and Laboratory Analyses}

On the last day of each experimental period, starting at $0500 \mathrm{~h}$ (after the morning milking), a total of $6 \mathrm{blood}$ samples, 1 sample every $2 \mathrm{~h}$, were collected from each of the 8 cows into heparinized tubes simultaneously from the coccygeal vessel and subcutaneous abdominal vein by venipuncture covering 3 cycles of feeding and 1 milking interval. Blood was placed on ice and centrifuged 
$\left(25 \mathrm{~min}, 1,800 \times g\right.$ at $4^{\circ} \mathrm{C}$ ) within $30 \mathrm{~min}$ of collection to yield plasma. For AA analysis, 2 aliquots of $1 \mathrm{~g}$ of plasma was immediately added to $0.2 \mathrm{~g}$ of one of 2 internal standards of AA labeled with stable isotopes and the processed samples were frozen at $-80^{\circ} \mathrm{C}$. One internal standard solution was prepared with labeled AA diluted in water with the following concentration $(\mu M)$ : DL- $\left[{ }^{15} \mathrm{~N}\right]$ His- $\alpha(180)$, L- $\left[{ }^{15} \mathrm{~N}\right]$ Ile $(708), \mathrm{L}-\left[1-{ }^{13} \mathrm{C}\right]$ Leu (864), DL- $\left[2-{ }^{15} \mathrm{~N}\right]$ Lys-2HCl (486), DL- $\left[1-{ }^{13} \mathrm{C}\right]$ Met (86), L- $\left[1-{ }^{13} \mathrm{C}\right]$ Phe $(247)$, L- $\left[{ }^{15} \mathrm{~N}\right] \mathrm{Thr}(375)$, L- $\left[{ }^{15} \mathrm{~N}\right] \mathrm{Val}$ (835), L- $\left[1-{ }^{13} \mathrm{C}\right]$ Ala $(1,060), \quad$ L- $\left[{ }^{[5} \mathrm{N}\right] \mathrm{Cys} \quad(227), \quad$ L- $\left[1-{ }^{13} \mathrm{C}\right] \mathrm{Glu}$ (273), L- $\left[1-{ }^{13} \mathrm{C}\right]$ Gln $(949), \mathrm{L}-\left[1-{ }^{13} \mathrm{C}\right]$ Gly $(1,131), \mathrm{L}-\left[1-{ }^{13} \mathrm{C}\right]$ Ser (491), and $\mathrm{L}^{-\left[{ }^{15} \mathrm{~N}\right] \mathrm{Tyr}}$ (245). The second internal standard solution contained labeled AA in the following concentration $(\mu M)$ : L- $\left[\right.$ guanido $\left.-{ }^{15} \mathrm{~N}_{2}\right] \operatorname{Arg}$ (400), L-[ureido- $\left.{ }^{13} \mathrm{C}\right] \mathrm{Cit}(422)$, and L- $\left[{ }^{15} \mathrm{~N}_{2}\right]$ Orn (240). Labeled AA (95-99 atom \%) were used; CDN Isotopes (Montreal, Quebec, Canada) supplied His, Leu, Lys, Met, and Phe, and Cambridge Isotope Laboratories (Andover, MA) supplied the others. The remainder of the plasma was stored at $-20^{\circ} \mathrm{C}$ for subsequent analyses.

Milk fat, protein, and lactose were measured by infrared spectroscopy at the Central Milk Testing Laboratory (Edmonton, Alberta, Canada). Milk NPN, $\mathrm{CN}$, and AA analyses were performed as described in Raggio et al. (2006). Feed ingredients were analyzed for CP (nitrogen $\times$ 6.25) using a Leco FP-428 Nitrogen Determinator (Leco Corporation, St. Joseph, MI) and for ADF and NDF using the procedures of Van Soest et al. (1991). Plasma AA concentrations were measured by isotope dilution using GC-MS (Calder et al., 1999), with (heptafluorobutyric) AA derivative for Arg, Cit, and Orn and the $N$-(tert-butyldimethyl)AA derivative for all other AA. Acetate concentrations were determined using a commercial kit modified for a 96-well plate (Enzytec, Scil Diagnostics GmbH, Viernheim, Germany). Briefly, through the actions of acetyl-CoA-synthetase, L-malate dehydrogenase, and citrate synthase, acetate is converted to oxaloacetate and nicotinamide adenine dinucleotide (NADH) and the absorbance of NADH is read at $340 \mathrm{~nm}$. $\beta$-Hydroxybutyrate concentrations were determined by the procedure of Williamson and Mellanby (1974) adapted to a 96-well plate format; BHBA dehydrogenase catalyzes the oxidation of BHBA to acetoacetate, with an equimolar amount of NAD reduced to NADH. The absorbance of NADH is read at $340 \mathrm{~nm}$ and is directly proportional to the amount of BHBA in the sample. A colorimetric assay (Raabo and Terkildsen, 1960) using a glucose oxidase/peroxidase enzyme (no. P7119, Sigma, St. Louis, MO) and dihydrochloride (no. F5803, Sigma) was used to measure glucose concentration. A spectrophotometric method using lactate dehydrogenase was used to measure Llactate (Benson et al., 2002). Plasma urea N concentra-
Table 2. Ingredient and nutrient composition of the TMR fed to the cows throughout the study

\begin{tabular}{lc}
\hline Item, \% of diet DM unless noted & Amount \\
\hline Ingredient & \\
Alfalfa hay & 13.4 \\
Barley silage & 32.9 \\
Corn grain & 13.0 \\
Beet pulp & 11.9 \\
Barley grain & 11.6 \\
Wheat grain & 6.2 \\
Canola seeds, ground & 6.2 \\
Ca soaps of fatty acids ${ }^{1}$ & 1.9 \\
Dicalcium phosphate & 0.70 \\
Vitamin/mineral premix ${ }^{2}$ & 0.85 \\
Sodium bicarbonate & 0.75 \\
Vitamin E, $5,000 \mathrm{IU} / \mathrm{kg}$ & 0.30 \\
Salt & 0.16 \\
Magnesium oxide & 0.06 \\
Nutrient & \\
NE ${ }^{3}{ }^{\text {Mcal } / \mathrm{kg}}$ & 1.77 \\
$\mathrm{CP}$ & 13.9 \\
$\mathrm{ADF}$ & 19.4 \\
$\mathrm{NDF}$ & 30.2 \\
Ca & 0.77 \\
$\mathrm{P}$ & 0.48 \\
$\mathrm{Mg}$ & 0.24 \\
$\mathrm{~K}$ & 1.30 \\
$\mathrm{MP},{ }^{3}$ g/d & 1,431 \\
\hline
\end{tabular}

${ }^{1}$ Megalac (Church \& Dwight Co. Inc., Princeton, NJ).

${ }^{2}$ Contained $0.1 \% \mathrm{Ca}, 0.6 \% \mathrm{P}, 0.3 \% \mathrm{Mg}, 11.5 \% \mathrm{Na}, 0.23 \% \mathrm{~S}, 6.2 \mathrm{mg} / \mathrm{kg}$ of Co, $1,170 \mathrm{mg} / \mathrm{kg}$ of Cu, $80 \mathrm{mg} / \mathrm{kg}$ of I, $3,100 \mathrm{mg} / \mathrm{kg}$ of Mn, $40 \mathrm{mg} /$ $\mathrm{kg}$ of Se, $5,000 \mathrm{mg} / \mathrm{kg}$ of $\mathrm{Zn}, 1,265,000 \mathrm{IU} / \mathrm{kg}$ of vitamin A, 142,000 $\mathrm{IU} / \mathrm{kg}$ of vitamin D, and $3,800 \mathrm{IU} / \mathrm{kg}$ of vitamin E.

${ }^{3}$ Calculated using DMI of $16.3 \mathrm{~kg} / \mathrm{d}$ (NRC, 2001).

tions were measured with an automatic analyzer (Technicon Autoanalyser II, Technicon Instruments Corp., Tarrytown, NY) using the diacetyl monoxime method as described previously (Huntington, 1984). Plasma insulin concentrations were determined by RIA using a Coat-A-Count Insulin Kit (Diagnostic Products Corp., Los Angeles, CA). Concentrations of IGF-1 were determined by a double-antibody RIA following acid-ethanol extraction (Novak et al., 2002). Both insulin and IGF-1 were determined in a single assay, with intraassay coefficients of variation being 7.0 and $6.7 \%$ for insulin and IGF-1, respectively.

\section{Calculations}

Milk AA output was calculated using milk protein yield measured on the last day of each period, with a 3.5\% correction for blood-borne proteins, and AA composition as analyzed for this study (mg of AA/g of true protein: Ala: 34.2; Gly: 19.9; His: 29.8; Leu: 106.1; Lys: 89.4; Phe: 52.1; Pro: 103.7; Thr: 46.6; Tyr: 54.1 ) or calculated from an average composition of milk protein fractions and AA composition when not available from our analysis (Arg: 36.2; Asn: 42.4; Asp: 35.4; Cys: 7.1; Gln: 98.9; Glu: 126.3; Ile: 61.4; Met: 30.7; 
Ser: 62.9; Trp: 14.9; Val: 69.2; adapted from Swaisgood, 1995). Mammary plasma flow was estimated according to the Fick principle using Phe and Tyr as internal markers, again with allowance for a $3.5 \%$ contribution from blood-borne proteins: mammary plasma flow $=$ $[($ milk Phe + Tyr $) \times 0.965] /($ arteriovenous difference Phe + Tyr) (Cant et al., 1993), using milk protein yield of the last experimental day. The net fluxes of nutrients across the MG were calculated for each cow period as the product of the average plasma arteriovenous concentration difference and the average plasma flow. A positive flux indicates utilization or removal, whereas a negative flux indicates net release of the nutrient across the MG.

\section{Statistical Analysis}

Metabolite concentrations were averaged over the 6 sampling times on d 14 of each period, and DMI, milk yield, and milk composition were averaged over the last $7 \mathrm{~d}$ of each period. Concentrations, net fluxes, uptake:output ratios, and animal performance data were analyzed using the MIXED procedure of SAS (SAS Institute Inc., 1999) with a statistical model that included treatment, period, and parity as fixed effects and cow(parity) as the random effect. A parity $\times$ treatment effect was initially tested in the model but there were no significant effects for any of the measured parameters, so this interaction was subsequently removed. Cow was the experimental unit.

Preplanned contrasts, based on the factorial design, were used to determine the effect of treatments. The EAA contrast compares the treatments where essential AA are present with the other treatments (i.e., the average of ETL + TOT to the average of CTL + NETL). Likewise, the NEAA contrast compares the NEAA treatments with the other treatments (i.e., the average of NETL + TOT to the average of CTL + ETL). The final contrast, denoted as INT, examines the interaction between EAA and NEAA and compares the average of CTL + TOT to the average of ETL + NETL. Treatment differences were considered significant if $P \leq 0.05$ and as a trend for $0.05<P \leq 0.10$. The abomasal cannula became plugged with abomasal contents in 1 cow during the third period and so the cow was not used for periods 3 and 4 . Therefore, $\mathrm{n}=8$ for CTL and ETL and $n=7$ for NETL and TOT. All data are reported as least squares means with pooled standard errors of the mean.

\section{RESULTS}

\section{DMI and Milk Yield}

During the course of the experiment the cows were limited in feed intake to their preexperiment level of intake and had no feed refusals, thereby negating any effect of treatment on DMI (Table 3). Milk yield was higher for the cows receiving the EAA $(P<0.001$ for EAA contrast), averaging $37.4 \mathrm{~kg} / \mathrm{d}$ for the EAA treatments versus $33.4 \mathrm{~kg} / \mathrm{d}$ for the other 2 treatments (Table $3)$. Similarly, milk protein yield and concentration were also higher for the cows receiving the EAA $(P<0.001)$. Milk fat yield (average of $990 \mathrm{~g} / \mathrm{d}$ ) did not differ among the treatments, whereas milk fat concentration tended to be lower when cows were infused with EAA $(P=$ $0.10 ; 2.75$ vs. $2.93 \%$ ). Interestingly, milk lactose yield was higher $(P=0.002)$ for the EAA treatments than for the other treatments $(1,713$ vs. $1,560 \mathrm{~g} / \mathrm{d})$, but milk lactose content was lower $(P=0.002 ; 4.58$ vs. $4.67 \%)$. Casein as a percentage of true protein was lower $(P=$ $0.03 ; 84.1$ vs. $85.2 \%)$ and NPN as a percentage of CP tended to be higher $(P=0.08 ; 5.6$ vs. $5.0 \%)$ with the NEAA treatments. There was no interaction between EAA and NEAA on any measured milk parameters.

Dry matter intake was lower $(P=0.01)$ for first-lactation cows compared with second-lactation cows (14.0 vs. $18.2 \mathrm{~kg} / \mathrm{d}$; $\mathrm{SEM}=0.84)$. Milk yield was lower $(P=$ $0.03)$ for primiparous cows compared with multiparous cows $(32.2$ vs. $38.6 \mathrm{~kg} / \mathrm{d} ; \mathrm{SEM}=1.62)$, whereas fat yield was unaffected $(0.96$ vs. $1.02 ; \mathrm{SEM}=0.10)$ and lactose $(1.46$ vs. $1.81 \mathrm{~kg} / \mathrm{d} ; \mathrm{SEM}=0.06)$ and protein $(0.90$ vs. $1.15 \mathrm{~kg} / \mathrm{d} ; \mathrm{SEM}=0.04)$ yields were lower for first-lactation cows compared with second-lactation cows.

\section{$A A$ and Urea}

As expected, arterial concentrations of all EAA (Arg, His, Ile, Leu, Lys, Met, Phe, Thr, Trp, and Val) were higher $(P<0.001)$ when EAA were infused compared with NETL and CTL (Table 4). Citrulline and Orn concentrations were also higher $(P<0.001)$ with the EAA treatments than with the other 2 treatments. Glutamine, Gly, Ser, and Tyr concentrations were lower $(P<0.05)$ with the EAA treatments. When NEAA were infused, concentrations of the NEAA infused either increased $(P \leq 0.05$ : Gln, Gly, Pro, Ser $)$, tended to increase $(P=0.06$ : Ala $)$, tended to decrease $(P=$ 0.06: Cys), or were unaffected by treatment (Asp, Glu). Concentrations of the EAA Arg, His, Lys, Met, Thr, and Trp decreased $(P<0.01)$. Parity had no effect on plasma AA concentrations with the exception of Cit and Trp, whose concentrations were lower in firstparity cows than in second-parity cows.

Urea concentrations were higher when the average of ETL and NETL treatments $(7.45 \mathrm{mM})$ was compared with the average of the CTL and TOT treatments (6.64 $\mathrm{m} M$; INT contrast, $P=0.05$ ). 
Table 3. Effect of AA infusions on DMI and milk production and composition

\begin{tabular}{|c|c|c|c|c|c|c|c|c|}
\hline Item & \multicolumn{4}{|c|}{ Treatment $^{1}$} & SEM & \multicolumn{3}{|c|}{$P$-value contrast ${ }^{2}$} \\
\hline DMI, $\mathrm{kg} / \mathrm{d}$ & 16.1 & 16.5 & 15.4 & 16.4 & 0.73 & 0.15 & 0.38 & 0.51 \\
\hline Fat yield, $\mathrm{g} / \mathrm{d}$ & 976 & 1,048 & 947 & 990 & 77.7 & 0.19 & 0.33 & 0.74 \\
\hline $\mathrm{CP}$ yield, $\mathrm{g} / \mathrm{d}$ & 951 & 1,085 & 921 & 1,144 & 36.7 & $<0.001$ & 0.62 & 0.15 \\
\hline Lactose yield, $\mathrm{g} / \mathrm{d}$ & 1,570 & 1,681 & 1,550 & 1,744 & 54.9 & 0.002 & 0.61 & 0.31 \\
\hline $\mathrm{CN}, \%$ of true protein & 85.0 & 85.3 & 83.5 & 84.7 & 0.89 & 0.09 & 0.03 & 0.27 \\
\hline $\mathrm{NPN}, \%$ of $\mathrm{CP}$ & 5.04 & 4.96 & 5.77 & 5.37 & 0.32 & 0.44 & 0.08 & 0.59 \\
\hline Lactose, $\%$ & 4.65 & 4.55 & 4.69 & 4.60 & 0.05 & 0.001 & 0.10 & 0.95 \\
\hline
\end{tabular}

${ }^{1} \mathrm{CTL}=$ water infusion; ETL $=$ essential AA infusion at $359 \mathrm{~g} / \mathrm{d}$; NETL = nonessential AA infusion at $356 \mathrm{~g} / \mathrm{d}$; TOT = essential AA infusion at $359 \mathrm{~g} / \mathrm{d}+$ nonessential AA infusion at $356 \mathrm{~g} / \mathrm{d}$, for a total of $715 \mathrm{~g} / \mathrm{d}$.

${ }^{2} P$-value for contrasts: EAA $=$ ETL + TOT vs. CTL + NETL $;$ NEAA $=$ NETL + TOT vs. CTL + ETL $;$ INT $=$ ETL + NETL vs. CTL + TOT.

Mammary plasma flow was not affected by parity $(P$ $=0.28$ ) but was different among treatments. Plasma flow was lower $(P=0.02)$ with the EAA treatments $(605 \mathrm{~L} / \mathrm{h})$ than with the other 2 treatments $(670 \mathrm{~L} / \mathrm{h}$; Table 5). Conversely, flow tended to be higher with the NEAA treatments $(661 \mathrm{~L} / \mathrm{h})$ than with the CTL and ETL treatments $(615 \mathrm{~L} / \mathrm{h} ; P=0.08)$.
Uptake of all infused EAA and of the NEAA Cys, Gln, Gly, Orn, Ser, and Tyr was greater when EAA were infused than when they were not infused (EAA contrast, $P<0.05$ ), whereas the uptake of Glu decreased with EAA treatments $(P=0.02$; Table 5$)$. The uptake of Orn $(P=0.02)$ increased and that of Cit $(P$ $=0.09)$ and Phe $(P=0.06)$ tended to increase with the

Table 4. Effect of AA infusions on arterial concentrations of AA and urea ${ }^{1}$

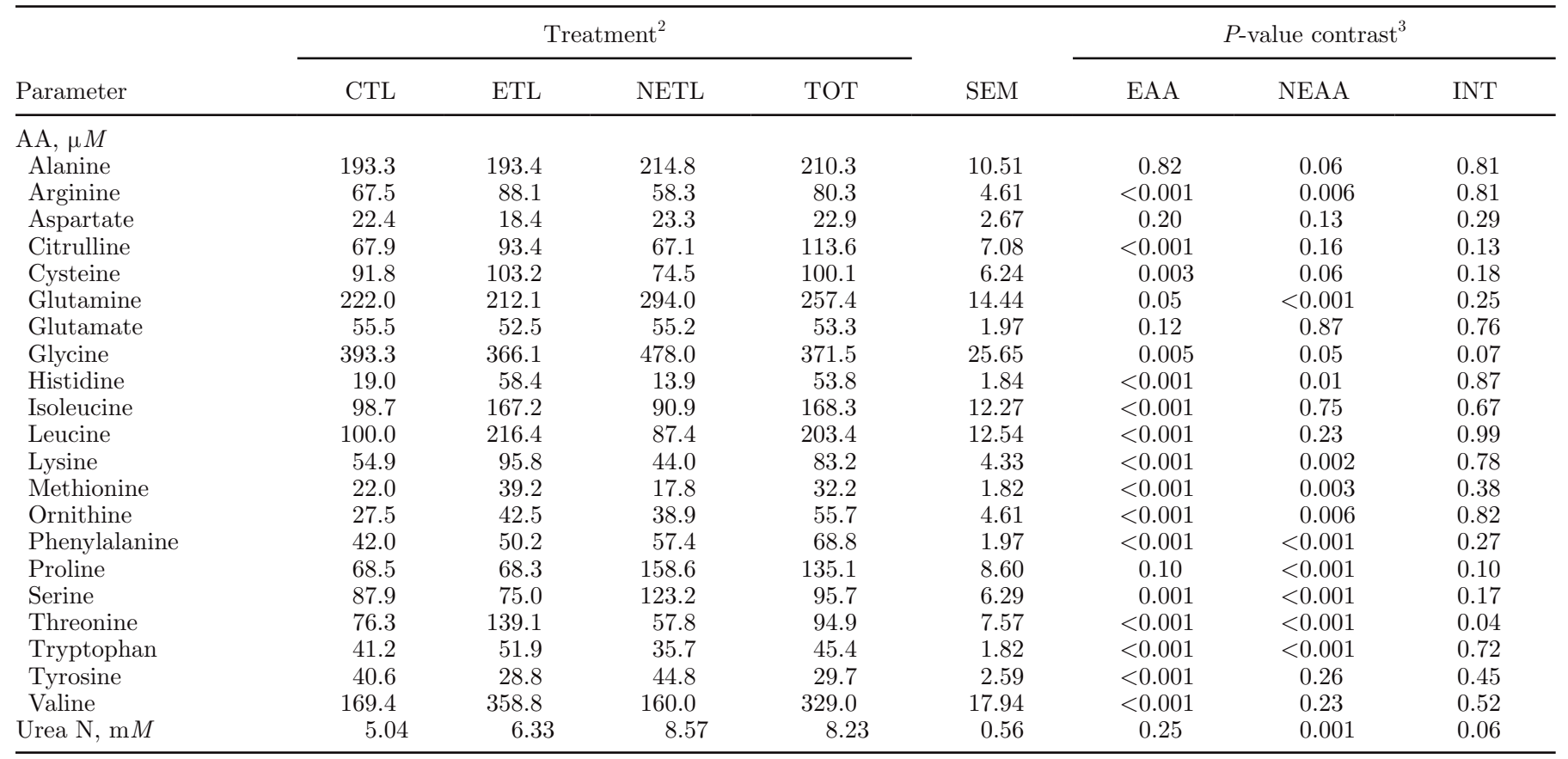

${ }^{1}$ Blood was obtained 6 times (every $2 \mathrm{~h}$ ) on the last day of each period.

${ }^{2} \mathrm{CTL}=$ water infusion; ETL $=$ essential AA infusion at $359 \mathrm{~g} / \mathrm{d}$; NETL $=$ nonessential AA infusion at $356 \mathrm{~g} / \mathrm{d}$; TOT $=$ essential AA infusion at $359 \mathrm{~g} / \mathrm{d}+$ nonessential AA infusion at $356 \mathrm{~g} / \mathrm{d}$, for a total of $715 \mathrm{~g} / \mathrm{d}$.

${ }^{3} P$-value for contrasts: EAA $=$ ETL + TOT vs. CTL + NETL; NEAA $=$ NETL + TOT vs. CTL + ETL $;$ INT $=\mathrm{ETL}+\mathrm{NETL}$ vs. CTL + TOT. 
Table 5. Effect of AA infusions on mammary plasma flow $(\mathrm{L} / \mathrm{h})$ and mammary gland AA uptake $(\mathrm{mmol} / \mathrm{h})^{1}$

\begin{tabular}{|c|c|c|c|c|c|c|c|c|}
\hline Item $^{2}$ & \multicolumn{4}{|c|}{ Treatment $^{3}$} & SEM & \multicolumn{3}{|c|}{$P$-value contrast ${ }^{4}$} \\
\hline Alanine & 17.2 & 16.6 & 10.1 & 17.6 & 3.29 & 0.10 & 0.16 & 0.06 \\
\hline Arginine & 20.5 & 22.3 & 17.8 & 22.6 & 1.39 & 0.02 & 0.38 & 0.29 \\
\hline Aspartate & 2.6 & 3.0 & 3.6 & 2.3 & 0.55 & 0.24 & 0.81 & 0.03 \\
\hline Glutamine & 33.3 & 37.0 & 34.0 & 39.3 & 2.34 & 0.03 & 0.45 & 0.66 \\
\hline Glutamate & 20.2 & 17.4 & 21.0 & 17.8 & 1.71 & 0.02 & 0.63 & 0.84 \\
\hline Glycine & 2.6 & 6.8 & -4.2 & 2.3 & 2.69 & 0.05 & 0.04 & 0.66 \\
\hline Histidine & 6.7 & 8.7 & 6.1 & 8.6 & 0.45 & $<0.001$ & 0.38 & 0.47 \\
\hline Isoleucine & 20.1 & 27.5 & 20.1 & 27.2 & 1.45 & $<0.001$ & 0.87 & 0.87 \\
\hline Leucine & 29.9 & 41.5 & 28.6 & 41.5 & 1.63 & $<0.001$ & 0.59 & 0.57 \\
\hline Lysine & 23.4 & 32.2 & 20.4 & 30.3 & 1.71 & $<0.001$ & 0.07 & 0.66 \\
\hline Threonine & 14.8 & 18.3 & 13.3 & 18.1 & 0.85 & $<0.001$ & 0.17 & 0.28 \\
\hline Tryptophan & 3.3 & 3.7 & 2.9 & 3.6 & 0.30 & 0.03 & 0.17 & 0.51 \\
\hline Tyrosine & 10.8 & 12.3 & 9.4 & 12.3 & 0.65 & $<0.001$ & 0.13 & 0.11 \\
\hline Valine & 24.0 & 33.9 & 23.4 & 32.0 & 1.84 & $<0.001$ & 0.34 & 0.62 \\
\hline Group 1 AA-N & 57.0 & 69.1 & 51.9 & 70.5 & 3.01 & $<0.001$ & 0.39 & 0.14 \\
\hline Group 2 AA-N & 120.7 & 194.3 & 114.6 & 167.0 & 15.39 & $<0.001$ & 0.24 & 0.44 \\
\hline EAA-N & 260.3 & 356.1 & 237.4 & 323.5 & 16.99 & $<0.001$ & 0.01 & 0.63 \\
\hline NEAA-N & 142.3 & 156.1 & 119.3 & 161.9 & 10.17 & $<0.001$ & 0.23 & 0.05 \\
\hline TAA-N & 402.6 & 512.2 & 354.9 & 483.6 & 24.54 & $<0.001$ & 0.006 & 0.42 \\
\hline
\end{tabular}

${ }^{1}$ Blood was obtained 6 times (every $2 \mathrm{~h}$ ) on the last day of each period.

${ }^{2}$ Group 1 AA-N = His, Met, Phe, Trp, and Tyr; group 2 AA-N = Ile, Leu, Lys, and Val; EAA-N = essential AA-N; NEAA-N = nonessential AA-N; TAA-N = total AA-N.

${ }^{3} \mathrm{CTL}=$ water infusion; ETL $=$ essential AA infusion at $359 \mathrm{~g} / \mathrm{d}$; NETL $=$ nonessential AA infusion at $356 \mathrm{~g} / \mathrm{d}$; TOT $=$ essential AA infusion at $359 \mathrm{~g} / \mathrm{d}+$ nonessential AA infusion at $356 \mathrm{~g} / \mathrm{d}$, for a total of $715 \mathrm{~g} / \mathrm{d}$.

${ }^{4} P$-value for contrasts: EAA $=$ ETL + TOT vs. CTL + NETL; NEAA $=$ NETL + TOT vs. CTL + ETL; INT $=$ ETL + NETL vs. CTL + TOT.

infusion of NEAA. Uptake of Gly was reduced when NEAA were infused (NEAA contrast, $P=0.04$ ) relative to the ETL and CTL treatments, whereas there was a tendency for uptake of Lys to be reduced $(P=0.07)$. Globally, the infusion of NEAA decreased the uptake of EAA-N (308 vs. $281 \mathrm{mmol} / \mathrm{h}$ ) and of total AA-N (457 vs. $419 \mathrm{mmol} / \mathrm{h} ; P<0.01)$. For Asp, Met, Pro, and Ser there was a significant INT contrast $(P \leq 0.05)$ and for Ala there tended $(P<0.10)$ to be a significant INT contrast, indicating that the response of the EAA was different when they were added to CTL than when they were added to the NEAA. For Pro, uptake with the ETL treatment was lower than that with CTL, whereas uptake with TOT was more than that with NETL. For Met and Ser, uptake relative to CTL decreased when NETL was infused but increased when TOT relative to ETL was infused. Overall, EAA infusions increased NEAA-N uptake, whereas the NEAA treatment decreased NEAA-N uptake only when infused alone (INT contrast, $P=0.05$ ).
For the majority of AA, mammary uptake was lower (Arg, His, Ile, Leu, Met, Phe, Ser, and Tyr) or tended to be lower (Trp and Val) in first-parity cows than in second-parity cows, which is consistent with the lower milk yield of the primiparous cows.

When EAA were infused, the mammary uptake:milk protein output ratio increased for Ile, Leu, Lys, Met, Ser, Thr, Val, and the group 2 AA $(P<0.05)$, tended to increase for Gly, His, and the group 1 AA $(P<$ $0.10)$, and decreased for Asp, Gln, and Glu $(P<0.05$; Table 6). The NEAA treatments resulted in decreased uptake:output ratios for Gly, Thr, Trp, and EAA-N and TAA-N. For several of the AA, there was or tended to be a significant INT contrast. For Ala $(P=0.05)$ and Pro $(P=0.006)$, the uptake:output ratio with the ETL treatment was lower than that with CTL but was higher with TOT relative to NETL. The uptake:output ratio for Ser and Met decreased when NETL was infused relative to CTL but increased when TOT relative to ETL was infused. The uptake:output ratio of 
Table 6. Effect of AA infusions on mammary gland AA uptake:milk protein output ratio ${ }^{1}$

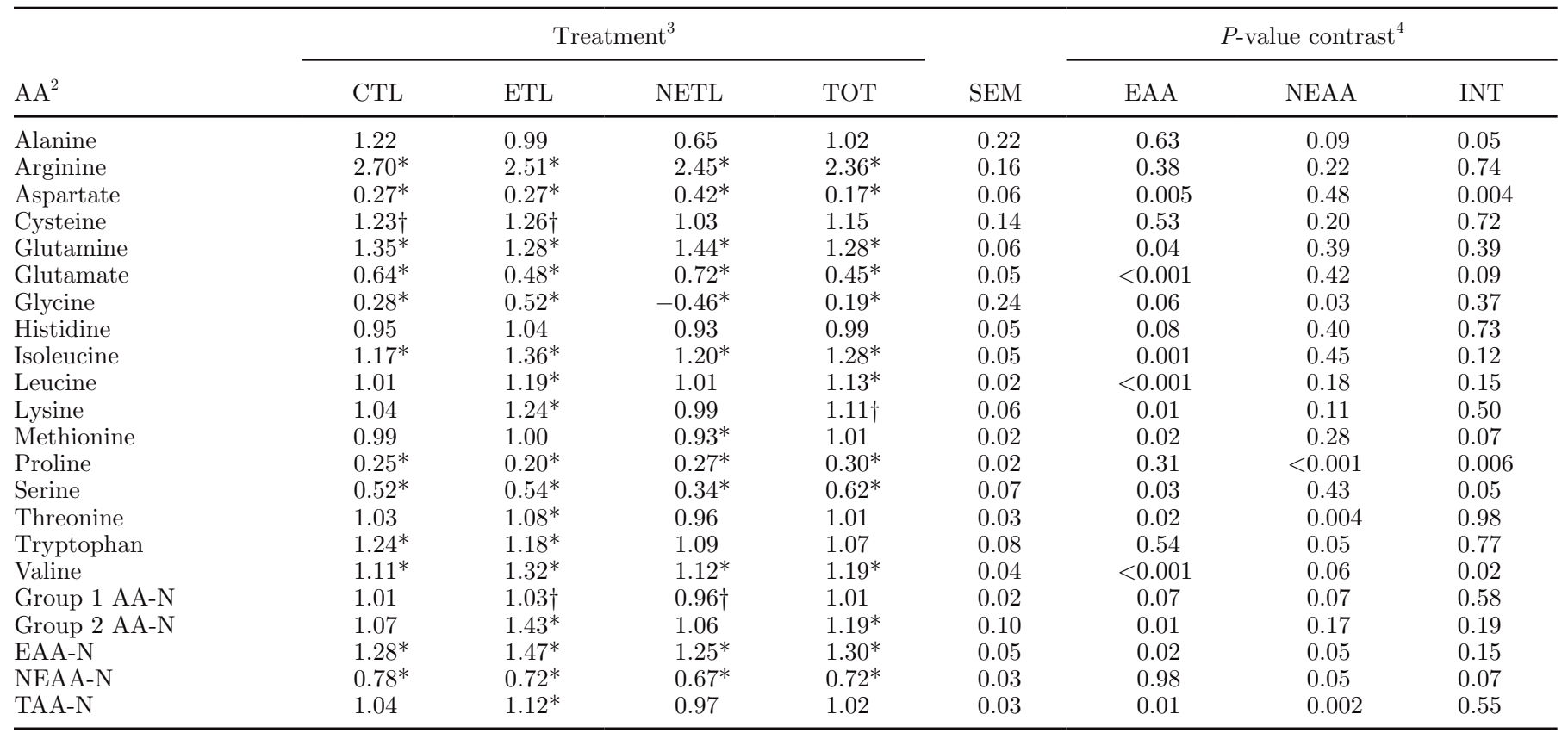

${ }^{1}$ Blood was obtained 6 times (every $2 \mathrm{~h}$ ) on the last day of each period.

${ }^{2}$ Group 1 AA-N = His, Met, Phe, Trp, and Tyr; group 2 AA-N = Ile, Leu, Lys, and Val; EAA-N = essential AA-N; NEAA-N = nonessential AA-N; TAA-N = total AA-N.

${ }^{3} \mathrm{CTL}=$ water infusion; $\mathrm{ETL}=$ essential AA infusion at $359 \mathrm{~g} / \mathrm{d}$; NETL $=$ nonessential AA infusion at $356 \mathrm{~g} / \mathrm{d}$; TOT = essential AA infusion at $359 \mathrm{~g} / \mathrm{d}+$ nonessential AA infusion at $356 \mathrm{~g} / \mathrm{d}$, for a total of $715 \mathrm{~g} / \mathrm{d}$.

${ }^{4} P$-value for contrasts: EAA $=$ ETL + TOT vs. CTL + NETL; NEAA $=$ NETL + TOT vs. CTL + ETL; INT $=$ ETL + NETL vs. CTL + TOT.

*Different from 1 at $P \leq 0.05 ; \dagger$ different from 1 at $0.05<P \leq 0.10$.

Asp was higher $(P<0.01)$ for NETL than CTL but decreased for TOT compared with NETL. With the exception of Gln, Lys, and Ser, parity had no effect on the uptake:output ratio (data not shown).

\section{Energy-Yielding Nutrients}

Acetate, BHBA, glucose, and lactate arterial concentrations were measured as indicators of energy status in the cows. None of these indicator concentrations were affected by treatment (Table 7) and averaged 1.28, 1.07, 3.94, and $0.78 \mathrm{mM}$ for acetate, BHBA, glucose, and lactate, respectively. Insulin concentration did not vary among the treatments $(P>0.10)$, but IGF-1 concentration was higher when EAA were infused (145.3 $\mathrm{ng} / \mathrm{mL})$ than when they were not $(116.4 \mathrm{ng} / \mathrm{mL} ; P=$ 0.008). Likewise, infusion of NEAA tended to increase IGF-1 concentrations $(P=0.09 ; 139.8$ vs. $121.9 \mathrm{ng} /$ $\mathrm{mL}$ ). Metabolite and hormone concentrations were not affected by parity.

With the exception of glucose, mammary uptake of individual energetic precursors did not differ among the treatments (Table 8). Uptake of acetate averaged $512 \mathrm{mmol} / \mathrm{h}$, whereas BHBA and lactate uptake aver- aged 204 and $188 \mathrm{mmol} / \mathrm{h}$, respectively. The combined uptake of BHBA and lactate tended, however, to be higher for the EAA treatments $(456 \mathrm{mmol} / \mathrm{h})$ than for the CTL and NETL treatments $(322 \mathrm{mmol} / \mathrm{h} ; P=$ $0.06)$. Glucose mammary uptake tended to be higher $(P=0.07)$ with the NEAA treatments $(558 \mathrm{mmol} / \mathrm{h})$ compared with the other treatments $(510 \mathrm{mmol} / \mathrm{h}$; Table 8). Parity had no effect on mammary uptake of energetic precursors with the exception of glucose, which averaged $480 \mathrm{mmol} / \mathrm{h}$ in first-lactation cows and $587 \mathrm{mmol} / \mathrm{h}$ in second-lactation cows $(P=0.02$; SEM $=20)$.

\section{DISCUSSION}

\section{Milk Yield and Composition}

Infusion of EAA to a MP-deficient diet was sufficient to elicit an increment in milk and milk protein yields that was not further enhanced by the addition of NEAA to the infusate. The increment in milk protein yield with EAA was obtained not solely through an increased milk yield but also through an increased protein concentration, whereas increased milk lactose yield 
Table 7. Effect of AA infusions on arterial metabolite, insulin, and IGF-1 concentrations ${ }^{1}$

\begin{tabular}{|c|c|c|c|c|c|c|c|c|}
\hline Parameter & \multicolumn{4}{|c|}{ Treatment $^{2}$} & SEM & \multicolumn{3}{|c|}{$P$-value contrast ${ }^{3}$} \\
\hline Acetate, $\mathrm{m} M$ & 1.30 & 1.30 & 1.18 & 1.35 & 0.11 & 0.18 & 0.59 & 0.18 \\
\hline Glucose, $\mathrm{m} M$ & 3.91 & 3.95 & 3.97 & 3.91 & 0.08 & 0.86 & 0.83 & 0.44 \\
\hline Lactate, $\mathrm{m} M$ & 0.75 & 0.82 & 0.75 & 0.80 & 0.11 & 0.54 & 0.93 & 0.95 \\
\hline Insulin, $\mu \mathrm{IU} / \mathrm{mL}$ & 9.35 & 10.19 & 10.09 & 10.74 & 1.50 & 0.39 & 0.47 & 0.91 \\
\hline
\end{tabular}

${ }^{1}$ Blood was obtained 6 times (every $2 \mathrm{~h}$ ) on the last day of each period except for insulin and IGF-1, which was collected 3 times (every 4 h). ${ }^{2} \mathrm{CTL}=$ water infusion; ETL = essential AA infusion at $359 \mathrm{~g} / \mathrm{d}$; NETL = nonessential AA infusion at $356 \mathrm{~g} / \mathrm{d}$; TOT = essential AA infusion at $359 \mathrm{~g} / \mathrm{d}+$ nonessential AA infusion at $356 \mathrm{~g} / \mathrm{d}$, for a total of $715 \mathrm{~g} / \mathrm{d}$.

${ }^{3} P$-value for contrasts: EAA $=\mathrm{ETL}+\mathrm{TOT}$ vs. CTL $+\mathrm{NETL} ; \mathrm{NEAA}=\mathrm{NETL}+\mathrm{TOT}$ vs. $\mathrm{CTL}+\mathrm{ETL} ; \mathrm{INT}=\mathrm{ETL}+\mathrm{NETL}$ vs. CTL + TOT.

was more driven by the increased milk yield because lactose percentage was actually lower with the EAA treatments than with the other treatments. Also, fat yield did not increase, resulting in a decreased fat concentration with EAA infusion. On average, $51 \%$ of the $\mathrm{N}$ and $86 \%$ of the $\mathrm{C}$ infused with EAA were recovered in milk components.

On the other hand, the lack of a milk yield response to the NEAA infusions (added to the CTL diet or the ETL infusion) is similar to that reported by Metcalf et al. (1996); in those cows with an MP intake equivalent to $104 \%$ of the AFRC (1993) recommendation, the milk yield response to a jugular infusion of both EAA and NEAA was no greater than that to an infusion of EAA only. Our study furthermore suggests that even when MP supply is deficient relative to requirements, the NEAA were not a limiting factor in terms of milk and milk protein yields, indicating that there were sufficient amounts supplied in the diet plus synthesized de novo to meet the needs for milk protein synthesis.

Milk lactose yield increased similarly in ETL-infused cows compared with TOT-infused cows. An increment in protein supply has been reported to increase concurrently the whole-body rate of appearance of glucose (see review by Lemosquet et al., 2007). Theoretically, however, more than half of the glucogenic potential of
CN originates from NEAA. The lack of a milk lactose response with the NEAA treatments in the present study would suggest that the increment in milk lactose secretion is not linked solely to increased glucose availability. Indeed, in a recent study (Lemosquet et al., 2009a), infusion of large amounts of 5 NEAA (Ala, Asp, Glu, Gly, and Ser) increased whole-body rate of appearance of glucose but decreased milk lactose yield. Examination of mammary metabolism might help to explain these apparent inconsistencies.

The increment in milk and milk component yields with the TOT treatment is in the range of those reported with $\mathrm{CN}$ infusions: the recovery as milk protein of the infusion of the whole mixture of AA compared with the CTL group was $26 \%$, higher than the $18 \%$ average that Hanigan et al. (1998) reported from a review of CN infusions. This difference may lie in the fact that our diet was deficient in protein and that the efficiency of transfer of absorbed protein into milk protein is dependent on protein supply (Doepel et al., 2004).

\section{$A A$}

The increase in EAA arterial concentrations with the EAA treatments was as expected: the infusions increased the duodenal flow of EAA by $51 \%$ over that

Table 8. Effect of AA infusions on mammary uptake ( $\mathrm{mmol} / \mathrm{h})$ of plasma metabolites

\begin{tabular}{|c|c|c|c|c|c|c|c|c|}
\hline \multirow[b]{2}{*}{ Item } & \multicolumn{4}{|c|}{ Treatment $^{1}$} & \multirow[b]{2}{*}{ SEM } & \multicolumn{3}{|c|}{$P$-value contrast ${ }^{2}$} \\
\hline & CTL & ETL & NETL & TOT & & EAA & NEAA & INT \\
\hline Glucose & 502 & 517 & 549 & 566 & 26.6 & 0.54 & 0.07 & 0.95 \\
\hline Lactate & 128 & 236 & 157 & 229 & 72.9 & 0.15 & 0.86 & 0.77 \\
\hline
\end{tabular}

${ }^{1} \mathrm{CTL}=$ water infusion; $\mathrm{ETL}=$ essential AA infusion at $359 \mathrm{~g} / \mathrm{d}$; NETL $=$ nonessential AA infusion at $356 \mathrm{~g} / \mathrm{d}$; TOT = essential AA infusion at $359 \mathrm{~g} / \mathrm{d}+$ nonessential AA infusion at $356 \mathrm{~g} / \mathrm{d}$, for a total of $715 \mathrm{~g} / \mathrm{d}$.

${ }^{2} P$-value for contrasts: EAA $=$ ETL + TOT vs. CTL + NETL; NEAA $=$ NETL + TOT vs. CTL + ETL; INT $=$ ETL + NETL vs. CTL + TOT. 
estimated from the basal diet fed to the CTL cows. Concentrations of Cit and Orn were also higher, probably because of stimulation of the urea cycle from the infused Arg as well as excess EAA. The concentration of Cys also increased as a consequence of the Met that was infused. In response to the NEAA infusions, Phe concentration increased as a result of Phe being used as a replacement for Tyr in the infusate because of the low water solubility of Tyr. With the exception of Phe (increase) and the branched-chain AA (no change), the concentration of the EAA decreased with the NEAA infusions. Urea concentrations increased with the NEAA treatments, so it is possible that the concentrations of the EAA decreased because of stimulation of the urea cycle in the liver to remove excess AA, as indicated by the increased Orn concentration with NEAA infusions. This might be responsible for the numerical decrease of milk protein yield observed only when NEAA were added to the CTL treatment and not when added to the ETL treatment. The fact that the branched-chain AA, which are not taken up by the liver in any appreciable amounts (Lapierre et al., 2005), did not decrease in concentration adds credence to the hypothesis that the other EAA were in fact metabolized within the liver.

Mammary uptake (Table 5) of the EAA increased by $37 \%$ with the EAA infusions, relatively more than the $16.7 \%$ increase in milk protein yield observed with the EAA treatments compared with the other treatments. However, the magnitude of the increment varied among the EAA, with Trp exhibiting the smallest increase and Leu the largest. This supports differences in the uses within the MG of the EAA. Indeed, this is demonstrated clearly when the group 1 AA (His, Met, Phe+Tyr, and Trp) are compared with those of group 2 (Ile, Leu, Lys, and Val). On a net basis, the net uptake of group 1 AA-N is used almost exclusively in the MG for milk protein secretion as evidenced by the 1:1 mammary uptake:milk protein output ratio of the AA in this group. Although there was a tendency for EAA treatments to increase this ratio and a tendency for NEAA treatments to decrease it, the uptake:output ratio of the group $1 \mathrm{AA}$ as a conglomerate never exceeded 1.03 regardless of the level of AA supply, and tended to differ from 1 in only the ETL and NETL treatments.

On the other hand, the uptake:output ratio of group 2 AA-N increased when the EAA treatments were imposed compared with the CTL and NETL treatments. Indeed, it was numerically greater than 1 in only the CTL- and NETL-infused cows. This indicated that with the EAA treatments, mammary uptake of group 2 AA-N increased at a faster rate than milk protein yield; this excess mammary uptake could be either oxidized or used for the synthesis of NEAA, and subsequently be used for milk protein synthesis. Indeed, Raggio et al.
(2006) reported an increment in Leu oxidation across the MG with $\mathrm{CN}$ infusion that accounted exactly for the difference between the increased mammary uptake and milk protein output. Lapierre et al. (2009) reported that mammary uptake of Lys increased with increased Lys supply and that this increased uptake was used for the synthesis of NEAA.

Uptake of total AA-N increased with the EAA treatments, with EAA-N accounting for the majority of this increased uptake because NEAA-N uptake decreased when EAA were added to the CTL treatment. The increased uptake of the EAA would support the higher milk protein synthesis seen with these treatments including NEAA synthesis within the gland. Conversely, uptake and the uptake:output ratio of total AA-N decreased with the NEAA treatments. Concomitant with the decreased uptake of total AA-N was an increased mammary uptake of glucose; this would suggest that glucose alleviates the need for AA to supply energy within the MG or that glucose may supply $\mathrm{C}$ skeletons within the MG to support NEAA synthesis.

It was hypothesized that infusion of NEAA would increase mammary uptake of the NEAA, but this was not observed. Two possible situations may explain this. First, when only NETL was infused, EAA may have been limiting for milk protein synthesis and thus there was no need to increase NEAA uptake. Second, when NEAA were infused in addition to EAA to yield the TOT treatment, the preference of the MG for group 2 AA compared with NEAA to support the increment in milk yield might offer an advantage because the synthesis of the NEAA from the group 2 AA will generate energy through oxidation.

\section{Energy-Yielding Nutrients}

With the EAA treatments, milk and milk lactose yields increased without a concurrent increase in mammary glucose uptake. Indeed, the lactose output:glucose uptake ratio increased from 0.73 with the NETL and CTL treatments to 0.82 with the EAA treatments $(P$ $=0.04$ ), which means that the MG had to obtain part of its energy from other nutrients. Although mammary uptake of acetate, BHBA, and lactate did not differ among treatments, when summed together, the uptake of BHBA plus lactate tended $(P=0.06)$ to increase with the infusion of EAA. Therefore, together these 2 compounds could have increased energy supply to the MG, thereby sparing glucose for lactose synthesis. Indeed, changes in uptake of glucose, acetate, BHBA, and lactate increased mammary uptake of $\mathrm{C}$ by 470 $\mathrm{mmol} / \mathrm{h}$ whereas the increment in lactose secretion averaged $180 \mathrm{mmol} / \mathrm{h}$ of C. Similarly, infusion of CN has been reported to increase milk lactose yield without a 
concurrent increment in glucose uptake, but with an increment in BHBA uptake, but only when energy was limiting (Lemosquet et al., 2009b). In a recent metaanalysis, however, Lemosquet et al. (2007) observed that although increasing protein supply increased milk yield, results were inconsistent to show a clear pattern in glucose and BHBA uptake to support the increased lactose secretion. In this latter analysis, increased protein supply also increased fat yield, but in the current study, fat yield was unaltered by any of the AA infusions.

Unlike the EAA treatments, mammary uptake of glucose tended to be higher with the NEAA treatments, whereas acetate and BHBA uptakes were unaffected. For the NEAA treatments (average of NETL and TOT), glucose incorporated into lactose averaged 0.74 of glucose uptake, whereas for the other treatments (average of CTL and ETL) incorporation into lactose accounted for 0.81 of glucose uptake. This is interestingly following the same pattern as the one observed with increased glucose or glucose precursor supply, where an increment in glucose availability increased mammary glucose uptake that was not paralleled by an increased lactose output (Lemosquet et al., 2009a,b). Although glucose concentration was not altered by NEAA treatments, it is possible that the NEAA infusions resulted in increased gluconeogenesis, as previously reported (Lemosquet et al., 2009a). Theoretically, the NEAA treatments could have yielded a maximal glucose synthesis of $52 \mathrm{mmol} / \mathrm{h}$, which was closely matched by the $48 \mathrm{mmol} / \mathrm{h}$ average increase in mammary uptake.

\section{Hormones}

Although insulin concentrations were the lowest for the CTL treatment, differences were not significant and changes in concentrations could not be related with variations in mammary metabolism. However, IGF-1 concentrations increased with both the EAA and NEAA treatments, being highest for the TOT treatment. This is in contrast to the study of Lemosquet et al. (2009b), in which a $\mathrm{CN}$ infusion did not elicit an IGF-1 response. However, in the current study, the basal diet supplied less protein and energy relative to requirements than the latter experiment.

\section{CONCLUSIONS}

The MG responded positively in terms of milk and milk protein yields to the supplementation of EAA, whereas there was no measurable response to NEAA supplementation. Mammary uptake of glucose did not increase to support the increased milk yield with EAA but uptake of BHBA plus lactate did, whereas mammary glucose uptake tended to be higher with the NEAA treatments. In contrast, mammary uptake of all EAA increased when essential AA were infused. The increase in milk yield with the EAA treatments without an increase in uptake of glucose but increased uptake of other energy-yielding substrates plus certain AA demonstrates the metabolic priority of milk production and the flexibility of the MG to use various substrates at its disposal to support it.

\section{ACKNOWLEDGMENTS}

The authors thank Tammy Whyte and Armagan Hayirli (both at University of Alberta, Edmonton, Alberta, Canada) for their help in planning and conducting the study, Steve Radostits (Leduc Veterinary Hospital, Leduc, Alberta, Canada) and Pascal Dubreuil (Faculté de Médecine vétérinaire, Université de Montréal, St-Hyacinthe, Quebec, Canada) for the surgical insertion of the abomasal catheters, and the staff at the University of Alberta Dairy Research and Technology Centre for the care of the experimental animals. We also thank Mario Léonard and Jocelyne Renaud of Dairy and Swine Research and Development Centre (Agriculture and Agri-Food Canada, Sherbrooke, Quebec, Canada) and Jocelyn Montgomery (University of Alberta, Edmonton, Alberta, Canada) for the laboratory analysis of the milk, plasma, and feed samples. Finally, we acknowledge the Alberta Livestock Industry Development Fund and Alberta Milk for their financial support of this project.

\section{REFERENCES}

Agriculture and Food Research Council. 1993. Energy and Protein Requirements of Ruminants. An advisory manual prepared by the AFRC technical committee of responses to nutrients. CABI, Wallingford, UK.

Benson, J. A., C. K. Reynolds, P. C. Aikman, B. Lupoli, and B. E. Beever. 2002. Effects of abomasal long chain fatty acid infusion on splanchnic nutrient metabolism in lactating dairy cows. J. Dairy Sci. 85:1804-1814.

Calder, A. G., K. E. Garden, S. E. Anderson, and G. E. Lobley. 1999. Quantitation of blood and plasma amino acids using isotope dilution electron impact gas chromatography/mass spectrometry with U-13C amino acids as internal standards. Rapid Commun. Mass Spectrom. 13:2080-2083.

Canadian Council on Animal Care. 1993. Guide to the Care and Use of Experimental Animals. Vol. 1. 2nd ed. E. D. Olfert, B. M. Cross, and A. A. McWilliam, ed. CCAC, Ottawa, Ontario, Canada.

Cant, J. P., E. J. DePeters, and R. L. Baldwin. 1993. Mammary amino acid utilization in dairy cows fed fat and its relationship to milk protein depresssion. J. Dairy Sci. 76:762-774.

Clark, J. H. 1975. Lactational responses to postruminal administration of proteins and amino acids. J. Dairy Sci. 58:1178-1197.

Doepel, L., M. Lessard, N. Gagnon, G. E. Lobley, J. F. Bernier, P. Dubreuil, and H. Lapierre. 2006. Effect of glutamine supplementation on immune response and milk production in dairy cows. J. Dairy Sci. 89:3107-3121.

Doepel, L., G. E. Lobley, J. F. Bernier, P. Dubreuil, and H. Lapierre. 2007. Effect of glutamine supplementation on splanchnic metabolism in lactating dairy cows. J. Dairy Sci. 90:4325-4333. 
Doepel, L., D. Pacheco, J. J. Kennelly, M. D. Hanigan, I. F. López, and H. Lapierre. 2004. Milk protein synthesis as a function of amino acid supply. J. Dairy Sci. 87:1279-1297.

Guinard, J., and H. Rulquin. 1995. Effects of graded amounts of duodenal infusions of methionine on the mammary uptake of major milk precursors in dairy cows. J. Dairy Sci. 78:2196-2207.

Hanigan, M. D., J. P. Cant, D. C. Weakley, and J. L. Beckett. 1998. An evaluation of postabsorptive protein and amino acid metabolism in the lactating dairy cow. J. Dairy Sci. 81:3385-3401.

Huntington, G. B. 1984. Net absorption of glucose and nitrogenous compounds by lactating Holstein cows. J. Dairy Sci. 67:1919 1927.

Lapierre, H., R. Berthiaume, G. Raggio, M. C. Thivierge, L. Doepel, D. Pacheco, P. Dubreuil, and G. E. Lobley. 2005. The route of absorbed nitrogen into milk protein. Anim. Sci. 80:11-22.

Lapierre, H., L. Doepel, E. Milne, and G. E. Lobley. 2009. Responses in mammary and splanchnic metabolism to altered lysine supply in dairy cows. Animal 3:360-371.

Lapierre, H., E. Milne, J. Renaud, and G. E. Lobley. 2003. Lysine utilization by the mammary gland. Pages $777-780$ in Progress in Research on Energy and Protein Metabolism. EAAP publication no. 109. W. B. Souffrant and C. C. Metges, ed. Wageningen Academic Publishers, Wageningen, the Netherlands.

Lemosquet, S., E. Delamaire, H. Lapierre, J. W. Blum, and J. L. Peyraud. 2009a. Effects of glucose, propionic acid, and nonessential amino acids on glucose metabolism and milk yield in Holstein dairy cows. J. Dairy Sci. 92:3244-3257.

Lemosquet, S., G. Raggio, H. Lapierre, J. Guinard-Flament, and H. Rulquin. 2007. Effects of protein supply on whole body glucose rate of appearance (Ra) and mammary gland metabolism of energetic nutrients in ruminants. Pages 581-582 in Energy and Protein Metabolism and Nutrition. EAAP publication no. 124. I. OrtiguesMarty, ed. Wageningen Academic Publishers, Wageningen, the Netherlands.

Lemosquet, S., G. Raggio, G. E. Lobley, H. Rulquin, J. GuinardFlament, and H. Lapierre. 2009b. Whole body glucose metabolism and mammary energetic nutrient metabolism in lactating dairy cows receiving digestive infusions of casein and propionic acid. J. Dairy Sci. 92:6068-6082.

Mepham, T. B. 1982. Amino acid utilization by lactating mammary gland. J. Dairy Sci. 65:287-298.
Metcalf, J. A., L. A. Crompton, D. Wray-Cahen, M. A. Lomax, J. D. Sutton, D. E. Beever, J. C. MacRrae, B. J. Bequette, F. R. C. Backwell, and G. E. Lobley. 1996. Responses in milk constituents to intravascular administration of two mixtures of amino acids to dairy cows. J. Dairy Sci. 79:1425-1429.

National Research Council. 2001. Nutrient Requirement of Dairy Cattle. 7th rev. ed. Nat. Acad. Sci., Washington, DC.

Novak, S., B. K. Treacy, F. R. C. L. Almeida, J. Mao, W. C. Buhi, W. T. Dixon, and G. R. Foxcroft. 2002. Regulation of IGF-I and porcine oviductal secretory protein (pOSP) secretion into the pig oviduct in the peri-ovulatory period, and effects of previous nutrition. Reprod. Nutr. Dev. 42:355-372.

Raabo, E., and T. C. Terkildsen. 1960. On the enzymatic determination of blood glucose. Scand. J. Clin. Lab. Invest. 12:402-407.

Raggio, G., S. Lemosquet, G. E. Lobley, H. Rulquin, and H. Lapierre. 2006. Effect of casein and propionate supply on mammary protein metabolism in lactating dairy cows. J. Dairy Sci. 89:4340-4351.

Roets, E., A. M. Massart-Leën, R. Verbeke, and G. Peeters. 1979 Metabolism of $\left[\mathrm{U}^{14}{ }^{14} \mathrm{C} ; 2,3-{ }^{3} \mathrm{H}\right]$-L-valine by the isolated perfused goat udder. J. Dairy Res. 46:47-57.

Rubert-Alemán, J., G. Rychen, F. Casseron, F. Laurent, and G. J. Martin. $1999 .{ }^{15} \mathrm{~N}$ enrichment of casein amino acids in the milk from goats given a single intravenous dose of L- $\left[{ }^{15} \mathrm{~N}\right]$ leucine. J. Dairy Res. 66:283-288.

Rulquin, H. 1986. Influence de l'équilibre en acides amines de trois protéines infusées dans l'intestin grêle, sur la production laitière de la vache. Reprod. Nutr. Dev. 26:347-348.

SAS Institute Inc. 1999. SAS System for Mixed Models. SAS Institute Inc., Cary, NC.

Swaisgood, H. E. 1995. Protein and amino acid composition of bovine milk. Pages 464-468 in Handbook of Milk Composition. R. G. Jensen, ed. Academic Press, Toronto, Ontario, Canada.

Van Soest, P. J., J. B. Robertson, and B. A. Lewis. 1991. Methods for dietary fiber, neutral detergent fiber, and nonstarch polysaccharide in relation to animal nutrition. J. Dairy Sci. 74:3583-3597.

Williamson, D. H., and J. Mellanby. 1974. D-(-)-3-Hydroxybutyrate. Page 1836 in Methods of Enzymatic Analysis. Vol. 4. H. U. Bergmeyer, ed. Academic Press, New York, NY.

Wohlt, J. E., J. H. Clark, R. G. Derrig, and C. L. Davis. 1977. Valine, leucine, and isoleucine metabolism by lactating bovine mammary tissue. J. Dairy Sci. 60:1875-1882. 